\title{
Ptychadena in Mauritania and the first record of Ptychadena schillukorum
}

\author{
Alberto Sánchez-Vialas', Marta Calvo-Revuelta', Rafael Márquez² \\ I Collection of Amphibians and Reptiles, Museo Nacional de Ciencias Naturales-CSIC, C/José Gutiérrez Aba- \\ scal 2, 28006, Madrid, Spain 2 Fonoteca Zoológica. Dept. de Biodiversidad y Biología Evolutiva, Museo \\ Nacional de Ciencias Naturales-CSIC, C/José Gutiérrez Abascal 2, 28006, Madrid, Spain
}

Corresponding author: Alberto Sánchez-Vialas (albertosv@mncn.csic.es)

Academic editor: A. Ohler | Received 23 August 2016 | Accepted 12 April 2017 | Published 15 May 2017

http://zoobank.org/69BEED14-F9AE-4B3E-95CF-B906669487E5

Citation: Sánchez-Vialas A, Calvo-Revuelta M, Márquez R (2017) Ptychadena in Mauritania and the first record of Ptychadena schillukorum. ZooKeys 673: 125-133. https://doi.org/10.3897/zookeys.673.10265

\section{Abstract}

The study of specimens of the genus Ptychadena of the herpetological collection of the Museo Nacional de Ciencias Naturales de Madrid reveals the first record of Ptychadena schillukorum from Mauritania, extending the known distribution range of the species in West Africa more than $450 \mathrm{~km}$ northwards. A key is provided for the four Mauritanian species of Ptychadena to solve problems in identification encountered in previous studies.

\section{Keywords}

Herpetological collection, identification key, Ptychadena schillukorum, Sahel, taxonomic problems, West Africa

\section{Introduction}

Ptychadena Boulenger, 1917 is a genus of medium-sized Afrotropical frogs that comprises 50 known living species (Frost 2017) which occur mainly in savannahs and wetlands. Several species of Ptychadena share a similar appearance and show interspecific overlap in morphological variation hampering the identification of diagnostic 
characters (Poynton 1970, Rödel 2000). Padial et al. (2013) show a map of Mauritania with the known localities of all amphibian species represented except for Ptychadena, where the locations are pooled by genus, due to the ambiguity of its specific identification in literature. However, Guibé and Lamotte (1957) revised the Ptychadena of West Africa providing a morphological key and Bwong et al. (2009) and Dehling and Sinsch (2013) suggested that morphologically similar species of Ptychadena may be identified using quantitative and qualitative morphological data (Zimkus et al. 2017).

The western portions of the Sahel ecoregion includes a diversified group of species of Ptychadena, namely P. pumilio (Boulenger, 1920), P. bibroni (Hallowell, 1845), P. tellini (Peracca, 1904) (as P. schubotzi (Sternfeld, 1917)), P. longirostris (Peters, 1870), P. oxyrhynchus (Smith, 1849), P. trinodis (Boettger, 1881), P. mascareniensis (Dúmeril \& Bibron, 1841), P. tournieri (Guibé \& Lamotte, 1955), P. stenocephala (Boulenger, 1901), P. submascareniensis (Guibé \& Lamotte, 1953), P. retropunctata (Angel, 1949), and P. schillukorum (Werner, 1908) (as P. floweri, (Boulenger 1917)) (Rödel 2000). At the northwestern limit of this area, along southern Mauritania, Ptychadena is represented by three species: P. trinodis, P. mascareniensis and P. bibroni (Padial 2003, Padial et al. 2013, Padial and De la Riva 2004). Ptychadena mascareniensis comprise a group of closely related species widely distributed across Africa but the taxonomy and phylogenetic affinities of the western populations from Senegal to Mauritania are still unresolved (Padial and De la Riva 2004, Vences et al. 2004, Zimkus 2017).

Ptychadena trinodis differs from the other two species of Ptychadena recorded in Mauritania by the presence of a tarsal tubercle and by very large inner and outer metatarsal tubercles; in Mauritania it has been reported in two localities: Guelta Oumm Lebare and Guelta Metraucha. Ptychadena cf. mascareniensis is cited only at one locality in Mauritania: Zoueina; it differs from P. bibroni by a very subtle outer metatarsal tubercle, lack of supernumerary tubercles on toe IV, dorsal median ridges that reach the posterior edge of the eyes, different webbing formula $\left(2^{2 / 3}-3\right.$ in $P$. cf. mascareniensis and $2-2^{1 / 3}$ in $P$. bibroni), and by a continuous lateral ridge which is broken in P. bibroni. Ptychadena bibroni is known by two records in Mauritania: Kaedi and Mahmoûdé Lake (Lamotte and Ohler 1997, Rödel 2000, Padial 2003, Padial and De la Riva 2004) (Fig. 1).

Abrupt climate changes and hydrological fluctuations that took place in southern Mauritania during Pleistocene-Holocene, created a dynamic transitional zone promoting dispersal and contraction of distributional areas of Afrotropical species (Gasse 2000; Foley et al. 2003; Brito et al. 2014; Sow et al. 2015). Most amphibians in Mauritania are restricted to the southern part of the country where they inhabit the Sahel savanna ecoregion (including all known Ptychadena). Only Hoplobatrachus occipitalis, Sclerophrys xeros, and Tomopterna cryptotis, are present across the north in the Saharan realm (Padial et al. 2013).

In this note, a new species record of Ptychadena is reported from southern Mauritania based on material of the herpetological collection of the Museo Nacional de Ciencias Naturales of Madrid (MNCN) and on field data obtained by RM. 


\section{Material and methods}

The specimens of Ptychadena held at the National Museum of Natural Sciences of Madrid (MNCN-CSIC) were examined. Thirty-one specimens were collected in Mauritania: one specimen of Ptychadena trinodis (cited in Padial 2003), one of $P$. cf. mascareniensis (cited in Padial and De la Riva 2004) and 29 individuals identified by us as Ptychadena schillukorum. Four specimens studied of P. bibroni were collected in Senegal (Table 1). Most individuals of P. schillukorum (19) were collected in October 1998 by $\mathrm{RM}$, a few days after a (rare) event of rainfall in Southern Mauritania in the proximities of Aleg ("2 kilometers east of Aleg", coordinates: $17^{\circ} 04^{\prime} 41$ "N, 13 $3^{\circ} 53^{\prime} 41^{\prime \prime W}$, and "west limit of Lake Aleg", coordinates: $\left.17^{\circ} 08^{\prime} 2 " \mathrm{~N}, 14^{\circ} 04^{\prime} 0 " \mathrm{~W}\right)$. Additionally, 10 individuals (MNCN 43846-43855) were collected in October 2006 by J. M. Padial and I. De la Riva in Aleg surroundings (1730'10.0"N, 135' $50.1^{\circ} \mathrm{W}$ ) (Fig. 1).

Morphological characters used in this study for comparison between the species of Ptychadena from Mauritania are: tarsal tubercle, inner metatarsal tubercle, outer metatarsal tubercle, lateral ridge, dorsal ridge, thigh pattern, supernumerary tubercles on toes and webbing extension in the fourth toe (Table 1).

The measure of the range extension of P. schikullorum was taken by airline distance using Google Earth tool, from the northern most locality in West Africa at NiokoloKoba in Senegal to Aleg in Mauritania.

\section{Results and discussion}

The poor conditions in which we found the specimen of $P$. cf. mascareniensis collected in Mauritania by Padial and De la Riva (Padial and De la Riva 2004) makes its identification difficult due to the lack of morphological characters such as the dorsal and lateral ridges. The existence of three phalanges of the fourth toe free of web and the mottled pattern of thigh makes us question its identity (see Table 1). Unfortunately, the only existing picture provided by J. M. Padial (Fig. 5C) of the same specimen does not allow us to conclude its specific identification as Ptychadena of the mascareniensis group. Genetic samples of it will be analysed to solve this question (in prep.). In this work the criteria of Padial and De la Riva considering the presence of $P$. cf. mascareniensis in Mauritania are followed.

The morphology of the studied individuals of Ptychadena schillukorum from Mauritania fitted with the description of the species (Channing and Howell 2006, Rödel 2000): dorsal and lateral ridges are not continuous; the legs are relatively short: tibiotarsal articulation reaches the level of the eye; lack of tarsal tubercles; outer metatarsal tubercles are inconspicuous; the pattern of thigh are speckled (fine vermiculation); the webbing is reduced: 2.5-three phalanges of the fourth toe free of web and no supernumerary tubercles are present in the toes. Tympanum small: its diameter reaches less than 0.7 diameter of the eye. 


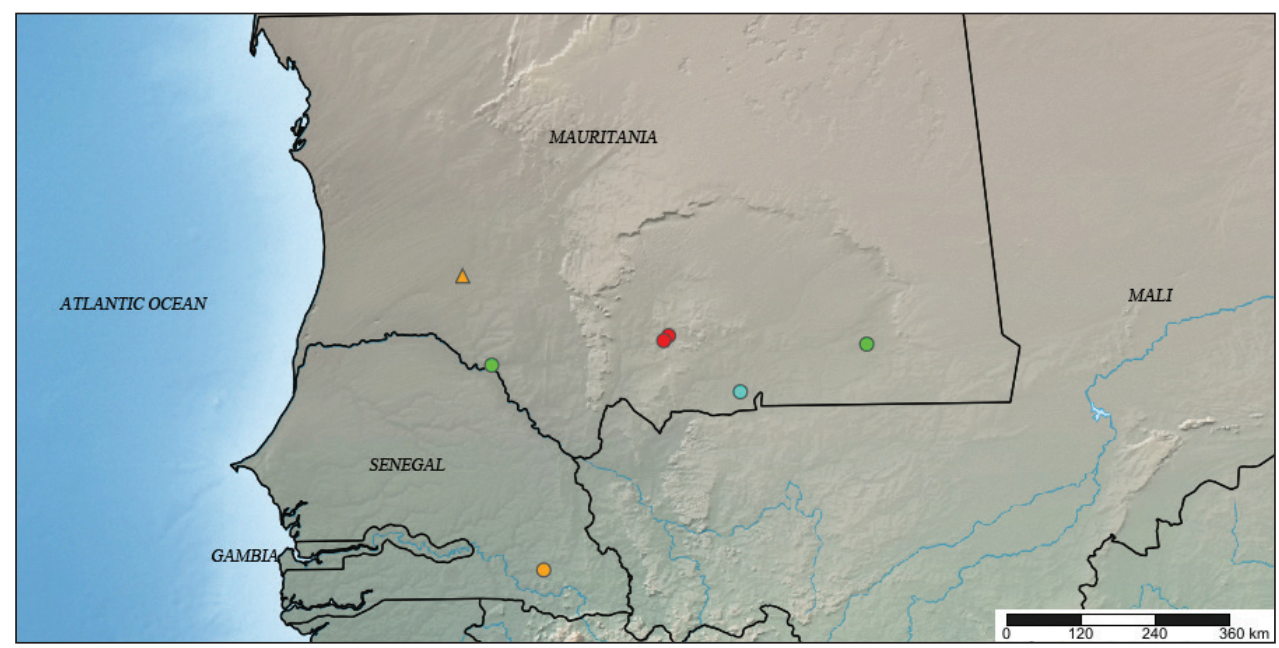

Figure I. Geographic records published of the species of Ptychadena from Mauritania identified at species level. Yellow dot from Senegal represent the previous northernmost record in West Africa of P. schillukorum. Green dot represent the localities were P. bibroni has been recorded in Mauritania. Localities with presence of $P$. trinodis are represented by red dots. The record of $P$. cf. mascareniensis is the blue coloured dot. The new record of $P$. schillukorum from Mauritania is shown as a yellow triangle (map created from http://www.simplemappr.net/).

Table I. Morphological characters of MNCN voucher specimens used in this study for comparing between the species of Ptychadena present in Mauritania.

\begin{tabular}{l|c|c|c|c}
\hline & P. bibroni & P. cf. mascareniensis & P. trinodis & P. schillukorum \\
\hline $\begin{array}{l}\text { Catalog number } \\
\text { (MNCN) }\end{array}$ & $44071-44074$ & 41784 & 41783 & $\begin{array}{c}43846-43855 ; 42221-42231 ; \\
42208 ; 42210-42216\end{array}$ \\
\hline Tarsal tubercle & absent & absent & present & absent \\
\hline $\begin{array}{l}\text { Inner metatarsal tubercle } \\
\text { as long as toe I }\end{array}$ & absent & absent & present & absent \\
\hline $\begin{array}{l}\text { Outer metatarsal tubercle } \\
\text { distinctive }\end{array}$ & present & absent & present & absent \\
\hline Lateral ridge continuous & absent & $?$ & present & absent \\
\hline Dorsal ridges continuous & present & $?$ & present & absent \\
\hline Mottled pattern of thigh & absent & present & absent & present \\
\hline $\begin{array}{l}\text { Number of phalanges of } \\
\text { toe 4 free of web }\end{array}$ & 2 & 3 & 2 & 3 \\
\hline $\begin{array}{l}\text { Supernumerary tubercles } \\
\text { on toe IV }\end{array}$ & present & absent & absent & absent \\
\hline
\end{tabular}

The examined individuals MNCN 42223, MNCN 42224, MNCN 42226, MNCN 42229, MNCN 42212, MNCN 42215, MNCN 42216 and MNCN 43849, present a thin yellow vertebral stripe. Therefore, the examined specimens are characterised by the tibia pattern with interrupted transversal bands. 


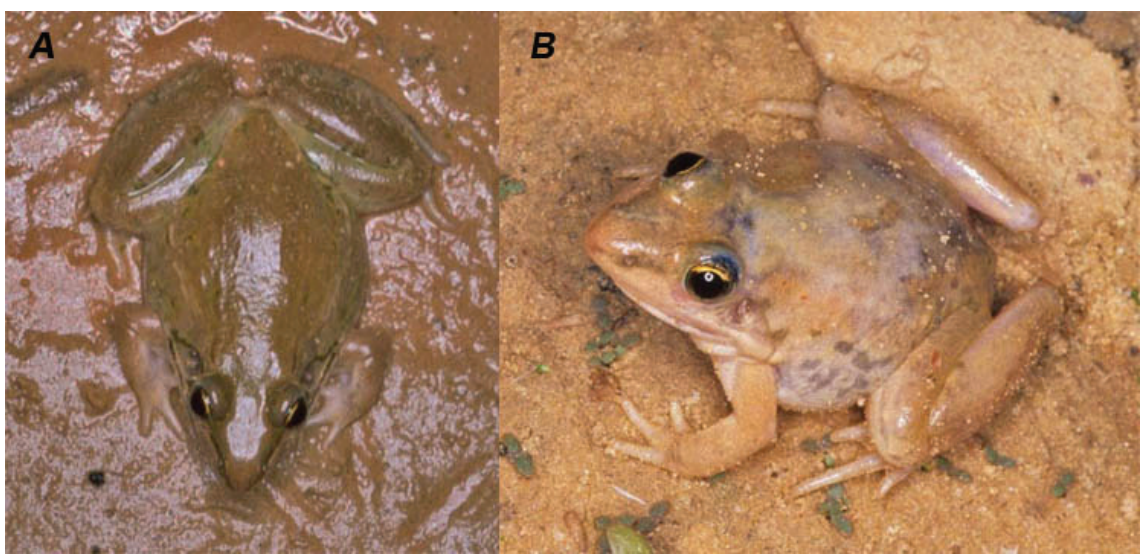

Figure 2. Different individuals of Ptychadena schillukorum from Aleg, Mauritania. Museum number of photographed specimens: A MNCN $42210(\mathrm{SVL}=32.7 \mathrm{~mm})$ B MNCN $42221(\mathrm{SVL}=27.3 \mathrm{~mm})$ (photos Rafael Márquez).

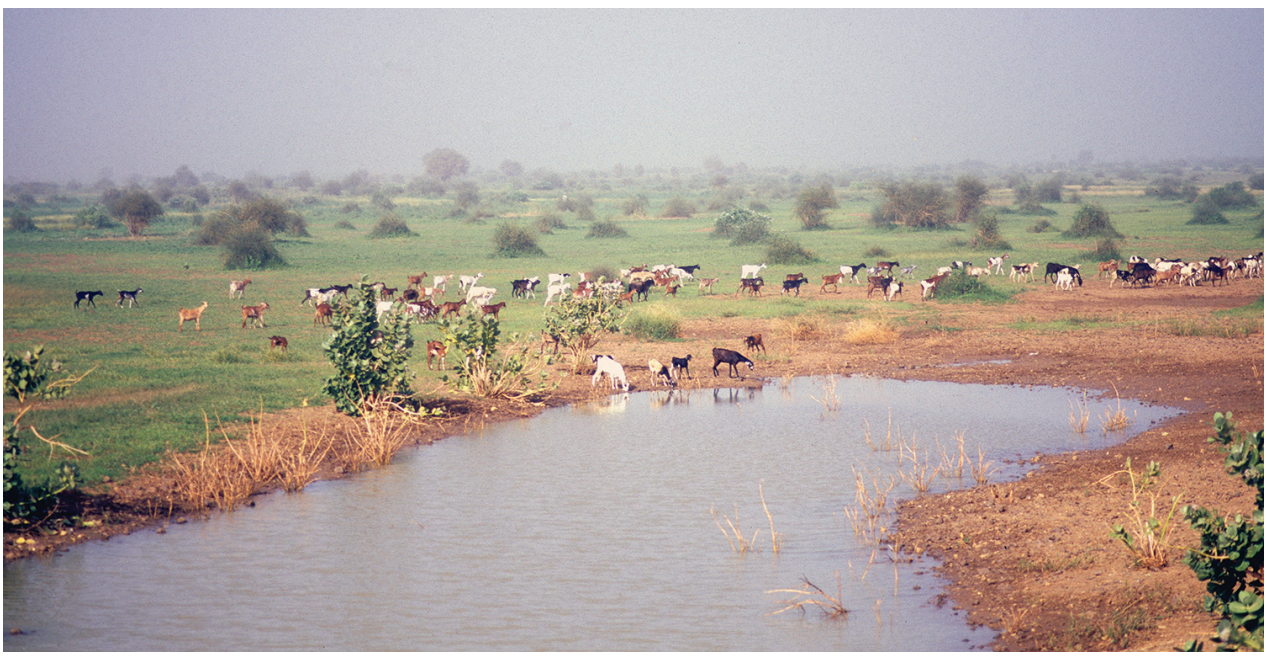

Figure 3. Temporal pond where Ptychadena schillukorum was found in Aleg, Mauritania (photo Rafael Márquez).

The nearest locality to Mauritania where Ptychadena schillukorum has been reported is in southern Senegal at Niokolo-Koba (Lamotte 1969, Joger and Lambert 2002). The record from Aleg in Mauritania extends $450 \mathrm{~km}$ northwards the distribution of the species (Fig. 1).

Ptychadena schillukorum (Fig. 2A, B) inhabits the dry savannahs and grasslands from Senegal to the extreme southern Somalia and also in isolation from Egypt (Baha el Din 2006, Nago et al. 2006) and southwards to east Africa from Kenya to Mozambique (Channing and Howell 2006). The reproduction of P. schillukorum in West Africa takes place in shallow savannah ponds during the rainy season (Nago et al. 2009). 


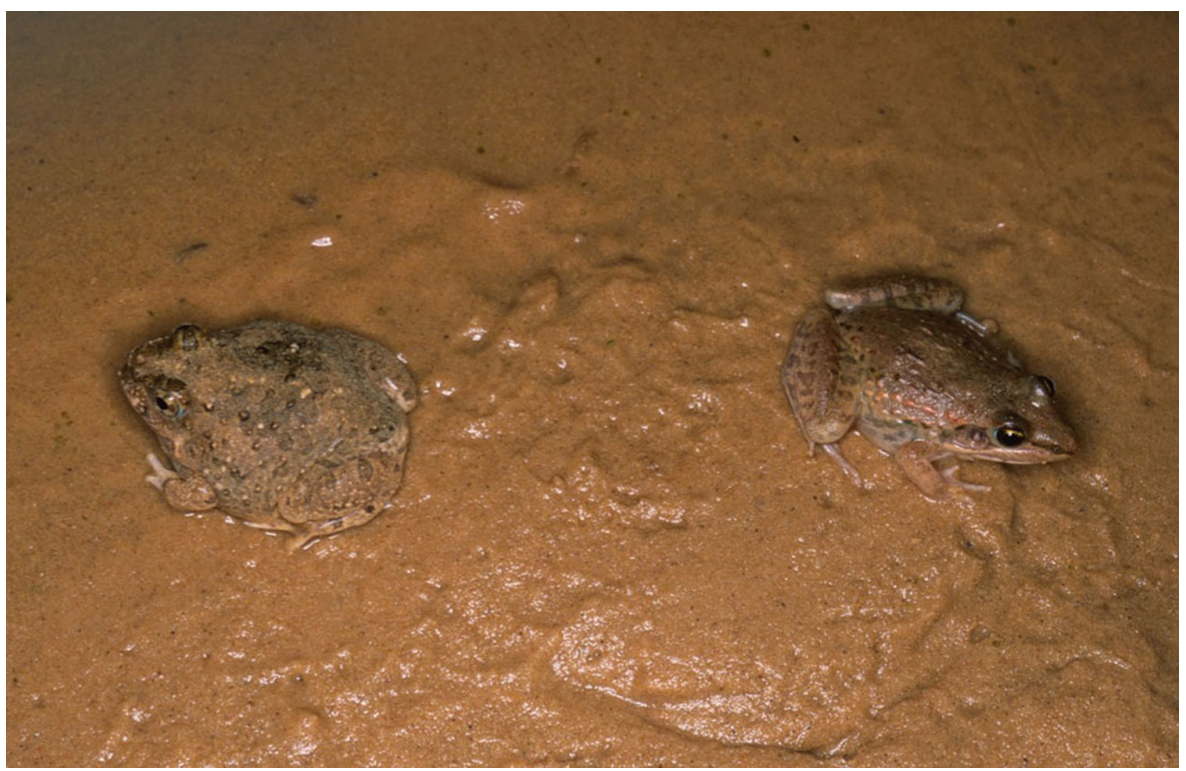

Figure 4. Tomopterna cryptotis and Ptychadena schillukorum (museum number: MNCN 42214, SVL $=31.8 \mathrm{~mm}$ ) found in syntopy, Aleg, Mauritania (photo Rafael Márquez).

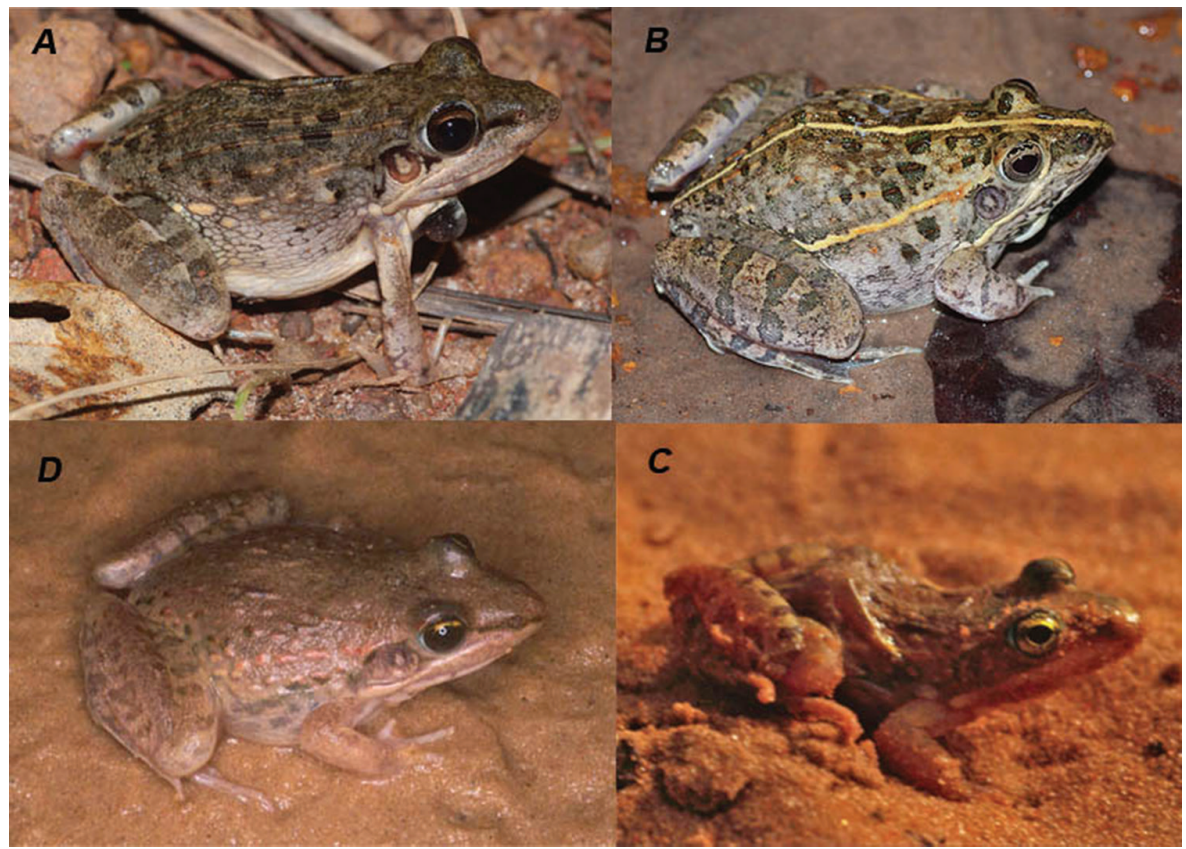

Figure 5. The four species of Ptychadena recorded in Mauritania: Ptychadena bibroni from Gourel Yoba, Senegal; male specimen, not collected (A), Ptychadena trinodis from Toubakouta, Senegal; male specimen, not collected (B), Ptychadena cf. mascareniensis from Zoueina, Mauritania (MNCN 41784, SVL=29.6 $\mathrm{mm})(\mathbf{C})$, Ptychadena schillukorum from Aleg, Mauritania (MNCN 42214, SVL=31.8 mm) (D) [photos Alberto Sánchez Vialas (A, B), José Manuel Padial (C) and Rafael Márquez (D)]. 
Aleg is located in the Sahel region, characterised by a subtropical dry arid climate with rainy season from July to October. Most individuals were collected in October 1998 by RM, a few days after a (sporadic) event of rainfall that caused the formation of shallow pools and the growth of herbaceous vegetation on the normally barren sand (Fig. 3). Other anuran species that were found concomitantly were Sclerophrys xeros and Tomopterna cryptotis (Fig. 4).

The four Mauritanian species of Ptychadena (Figure 5) are easily distinguishable from each other based on morphological characters. Ptychadena schillukorum differs from $P$. trinodis by the lack of tarsal tubercle, smaller inner metatarsal tubercle and inconspicuous outer metatarsal tubercle. Also a fine yellow vertebral line is sometimes present (8 of 29 specimens of $P$. schillukorum examined) while in $P$. trinodis a fine white-yellow vertebral line and light colored lateral ridge is generally present. Ptychadena schillukorum differs from P. bibroni by its more compact body, shorter legs, lack of supernumerary tubercles on toe IV, always interrupted dorsal ridges, by its inconspicuous outer metatarsal tubercle and by thigh pattern, that is speckled in P. schillukorum and usually with yellow longitudinal and irregular line in P. bibroni. Finally, P. schillukorum is distinctive from $P$. mascareniensis by its compact body shape, dorsal and lateral ridges, always interrupted, and shorter legs.

Based on Rödel (2000) and personal data, a key for the Ptychadena species that occur in Mauritania is presented.

\section{Key to the species of Ptychadena from Mauritania}

1 Tarsal tubercle present. Metatarsal tubercles large. Inner metatarsal tubercle

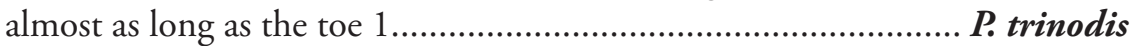

- $\quad$ Lack of tarsal tubercle. Inner metatarsal tubercle smaller than 0.6 of the

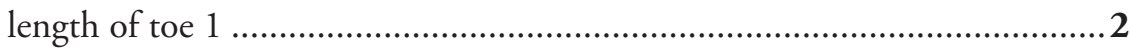

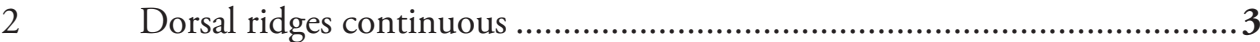

- Dorsal ridges discontinuous, broken into warts..................... P. schillukorum

3 Dorsal median ridges to mid-dorsum. Lateral ridge discontinuous. Supernumerary tubercles on toe IV present. P. bibroni

- $\quad$ Dorsal median ridges to posterior edge of the eyes. Lateral ridge continuous. Supernumerary tubercles on toe IV absent. P. mascareniensis

Studies concerning amphibian fauna in Mauritania are scarce, suggesting that other populations of Ptychadena schillukorum may be discovered in the future. Molecular studies of P. schillukorum should be carried out to know how complex is the species across their distribution (expected to be high or a group of species as suggested by Nago et al. 2006) and also to determine what is the systematic position and taxonomy of the Mauritanian population. 


\section{Acknowledgements}

We are grateful to Mario García París and Iñigo Martínez-Solano for advice and comments on the manuscript. Collection in Mauritania was possible thanks to Santiago Martínez de Orense who provided lodging, transportation, and help in the field.

This research was partially funded by project TATANKA (CGL2011-25062) obtained from Ministerio de Ciencia e Innovación, Spain. We are grateful to José Manuel Padial who kindly provided the picture 5C, and to Daniel Hinkley who revised the MS in English. We are also deeply grateful to Annemarie Ohler, Edgar Lehr and to an anonymous reviewer whose comments have helped in improving the manuscript.

\section{References}

Baha el Din S (2006) A Guide to the Reptiles and Amphibians of Egypt. The American University in Cairo Press, Cairo, Egypt, 320 pp.

Brito JC, Godinho R, Martínez-Freiría F, Pleguezuelos JM, Rebelo H, Santos X, Vale CG, VeloAntón G, Boratyński Z, Carvalho SB, Ferreira S, Gonçalves DV, Silva TL, Tarroso P, Campos JC, Leite JV, Nogueira J, Álvares F, Sillero N, Sow AS, Fahd S, Crochet PA, Carranza S (2014) Unravelling biodiversity, evolution and threats to conservation in the Sahara-Sahel. Biological Reviews 89(1): 215-231. https://doi.org/10.1111/brv.12049

Channing A, Howell K (2006) Amphibians of East Africa. Chimaira/Cornell University Press, $432 \mathrm{pp}$.

Bwong BA, Chira R, Schick S, Veith M, Lötters, S (2009) Diversity of Ridged Frogs (Ptychadenidae: Ptychadena) in the easternmost remnant of the Guineo-Congolian rain forest: an analysis using morphology, bioacoustics and molecular genetics. Salamandra 45(3): 129-146.

Dehling JM, Sinsch U (2013) Diversity of Ptychadena in Rwanda and taxonomic status of P. chrysogaster Laurent, 1954 (Amphibia, Anura, Ptychadenidae). ZooKeys 356: 69-102. https://doi.org/10.3897/zookeys.356.5878

Foley JA, Coe MT, Scheffer M, Wang G (2003) Regime shifts in the Sahara and Sahel: interactions between ecological and climatic systems in Northern Africa. Ecosystems 6: 524-539. https://doi.org/10.1007/s10021-002-0227-0

Frost DR (2017) Amphibian Species of the World: an Online Reference. Version 6.0 (08/02/2017). Electronic Database accessible at http://research.amnh.org/herpetology/ amphibia/index.html. American Museum of Natural History, New York, USA.

Gasse F (2000) Hydrological changes in the African tropics since the last glacial maximum. Quaternary Science Reviews 19: 189-211. https://doi.org/10.1016/S0277-3791(99)00061-X

Guibé J, Lamotte M (1957). Révision systématique des Ptychadena (Batraciens, Anoures Ranidés) d'Afrique occidentale. Bulletin de l'Institut Française d'Afrique Noire. Série A, Sciences Naturelles 19: 937-1003.

Joger U, Lambert M (2002) Inventory of amphibians and reptiles in SE Senegal, including the Niokola-Koba National Park, with observations on factors influencing diversity. Tropical Zoology 15(2): 165-185. https://doi.org/10.1080/03946975.2002.10531172 
Lamotte M (1969) Le parc national du Niokolo-Koba, Fascicule III; XXX. Amphibiens (deuxième note). Mémoires de l'Institut Fondamental d'Afrique Noire 84: 420-426.

Lamotte M, Ohler A (1997) Redécouverte de syntypes de Rana bibroni Hallowell, 1845, désignation d'un lectotype et description d'une espèce nouvelle de Ptychadena (Amphibia, Anura). Zoosystema 19(4): 531-543.

Nago SGA, Grell O, Sinsin B, Rödel M (2006) The amphibian fauna of Pendjari National Park and surroundings, northern Benin. Salamandra 42(2/3): 93-108.

Nago SGA, Sinsin BA, Rödel M (2009) The tadpole of Ptychadena schillukorum (Werner, 1908 “1907”) (Amphibia: Anura: Ptychadenidae). Zootaxa 2115: 65-68.

Padial J (2003) Ptychadena trinodis (MNCN) Mauritania. Herpetological Review 34(3): 260.

Padial JM, De La Riva I (2004) Annotated checklist of the amphibians of Mauritania (West Africa). Revista Española de Herpetología 18: 89-99.

Padial JM, Crochet PA, Geniez P, Brito JC (2013) Amphibian conservation in Mauritania. Basic and Applied Herpetology 27: 11-22. https://doi.org/10.11160/bah.13002

Poynton JC (1970) Guide to the Ptychadena (Amphibia: Ranidae) of the southern third of Africa. Annals of the Natal Museum 20: 365-375.

Rödel MO (2000) Herpetofauna of West Africa, Vol. I: Amphibians of the West African Savanna. Edition Chimaira, Frankfurt am Main, 335 pp.

Sow AS, Martínez-Freiría F, Crochet PA, Geniez P, Ineich I, Dieng H, Fahd S, Brito JC (2015) Atlas of the distribution of reptiles in the Parc National du Banc d'Arguin, Mauritania. Global Biodiversity 28: 99-111.

Vences M, Kosuch J, Rödel MO, Lötters S, Channing A, Glaw F, Böhme W (2004) Phylogeography of Ptychadena mascareniensis suggests transoceanic dispersal in a widespread African-Malagasy frog lineage. Journal of Biogeography 31(4): 593-601. https://doi. org/10.1046/j.1365-2699.2003.01031.x

Zimkus BM, Lawson P, Barej MF, Barratt DC, Channing A, Dash KM, Dehling MJ, Du Preez L, Gehring P, Greenbaum E, Gvoždík V, Harvey J, Kielgast J, Kusamba C, Nagy ZT, Pabijan M, Penner J, Rödel MO, Vences M, Lötters S (2017) Leapfrogging into new territory: How Mascarene ridged frogs diversified across Africa and Madagascar to maintain their ecological niche. Molecular Phylogenetics and Evolution 106: 254-269. https://doi. org/10.1016/j.ympev.2016.09.018 